MUZEUL NAȚIONAL DE ISTORIE A ROMÂNIEI

\title{
CERCETĂRI ARHEOLOGICE
} XII

Editor: Dr. Crişan Muşețeanu 
ISSN 0255-6812 


\section{CERCETĂRI ARHEOLOGICE}

XII

BUCUREŞTI

2003 
Editor: Dr. Crişan Muşețeanu

Redactor şef: Dragomir Popovici

Tehnoredactare: Daniela Iacovache, Cristina Joiţa Desene: Georgiana Ducman, Corina Dănilă

Foto: Marius Amarie

Coperta: Andrei Mărgărit

\section{Colectivul de redacție:}

Dr. Gheorghe Trohani

Dr. Liviu Petculescu

Dr. Anca Păunescu 


\section{CUPRINS}

\section{EMIL CONDURACHI}

REPERE BIOGRAFICE

Răzvan Theodorescu - Profesorul meu $\quad 15$

$\begin{array}{ll}\text { Zoe Petre - Pater } & 16\end{array}$

Alexandru Vulpe - Emil Condurachi - director 18

Mircea Petrescu-Dîmbovița - Academicianul Emil Condurachi la 90 ani de la naşstere 20

Ion Barnea - Emil Condurachi şi arheologia creştină

Alexandru Suceveanu - 90 de ani de la naşterea lui Emil Condurachi 29

Mihai Bărbulescu - Emil Condurachi - 90 de ani de la naştere 32

Constantin Preda - Profesorul Emil Condurachi-numismatul 34

Gavrilă Simion - Un cuvânt pentru profesorul meu

Mihai Irimia - Emil Condurachi Şi Dobrogea $\quad 40$

\section{RAPOARTE DE SĂPĂTURĂ}

Radu Coman, Elena Rența, Gh. Matei, Silviu Oța - Raport de cercetare arheologică pe anii 2001-2003 la Oraşul de Floci (com. Giurgeni, jud. Ialomița)

\section{ARTICOLE}

Radian Romus Andreescu, Traian Popa - Sultana-Malu Roşu. Catalog selectiv 59

Radian Romus Andreescu, Pavel Mirea, Ștefan Apope - Cultura Gumelnița în vestul Munteniei. Aşezarea de la Vităneşti, jud. Teleorman

Doina Leahu - Considerații cu privire la falerele de aur din epoca bronzului descoperite pe teritoriul României. 
Sorin Oanță-Marghitu - "Fenomenul Cernavoda III-boleráz": după 30 de ani

Rodica Boroffka, George Trohani - Necropola getică de la Canlia, com. Lipnița, jud.

Constanța

Doina Şeclăman, Marin Şeclăman, George Trohani - Contribuții la studiul ceramicii getice din Câmpia Română

Mircea Negru, Alexandru Bădescu, Romeo Avram - Amfore de tip käpitan II în Dacia romană

Silviu Oța, Katiuşa Pârvan - Monede medievale descoperite la Piua Petrii în campaniile arheologice din anii 1996, 1998-1999 (I)

Anca Păunescu, Eugen S. Teodor - L'établissement rural médiéval des XVI-XVII siecles de Brăneşti-Vadu Anei

\section{STUDII}

Mircea Anghelinu - Note privind impactul marxismului în teoria şi practica arheologiei preistorice din România

Dragomir Popovici - Area organization, arrangement and use in the Cucuteni, phase A Culture (I)

Eugen Silviu Teodor - O frontieră incertă a lumii romane - Câmpia Dunării de Jos în epoca lui Justinian

\section{CERCETĂRI PLURIDISCIPLINARE}

Adrian Bălăşescu, Valentin Radu - Studiul materialului faunistic descoperit in tell-ul de la Vităneşti (jud. Teleorman): nivelul Gumelniţa $B_{1}$

Constantin Haită, Valentin Radu - Les zones de rejets menageres de la culture Gumelnita: temoins dans l'evolution chrono - stratigraphique des tells. Etude micro-morphologique et archaeo-ichthyologique sur le tell d'Hârsova (dep. Constanța).

\section{NOTE}

Elvira Ciocea Safta - Un ac de bronz cu cap globular din Transilvania 
Lia Bătrîna, Adrian Bătrîna - Precizări cu privire la unele reprezentări de pe inele medievale din secolele XIV-XV

Adina Boroneanț, Mihai Vasile - Protecția monumentelor istorice în România. Partea I-a legislația şi aplicarea ei anterior anului 1989

\section{RECENZII}

Crişan Mușețeanu - Kevin Greene, The Pre Flavian Fine Wares, Report un the Excavations at Usk 1965-1976 University of Wales Press, Cardiff, 1979, 165 p., 55 figures.

Crişan Mușețeanu - Tatyana Cvjecticanin, Glazed pottery from Upper Moesia, Beograd, 2001, 149 pages, 8 illustrations, 2 maps.

Crişan Muşețeanu - Ioan C. Opriş, Ceramica romană târzie şi paleobizantină de la Capidava in contextul descoperirilor de la Dunărea de Jos (sec IV - VI p. Chr) 241 pagini, 64 planşe, editura Enciclopedică, Bucureşti 2003.

Silviu Teodor - Florin Curta - The Making of Slavs: History and archaeology on the Lower Danube Region, cca. 500-700 Oxford University Press, 2001 (350 p. + două anexe, index, bibliografie)

Rodica Oanță-Marghitu - Éva Garam, Funde byzantinischer Herkunft in der Awarenzeit vom Ende des 6. Bis zum Ende des 7. Jahrhunderts, în Monumenta Avarorum Archaeologica, Vol 5, Budapesta, 2001; 24 de figuri în text, 139 de planşe alb-negru, 60 de planşe color şi o anexă

\section{Necrolog}

\section{Radu Florescu}




\title{
RAPORT DE CERCETARE ARHEOLOGICĂ PE ANII 2001-2003 LA ORAȘUL DE FLOCI (COM. GIURGENI, JUD. IALOMIT,A)
}

\author{
Radu Coman, Elena Rența, Gheorghe Matei, Silviu Oța*
}

\begin{abstract}
The current paper presents a part of the archaeological researches performed between 2001 and 2003 at the archaeological site from Oraşul de Floci (Piua Petri point, Giurgeni, Ialomița County), on the sand bank no. 3 , with a special focus on the medieval necropolis.

A total number of six dwellings dating back from the XVth - XVIIth centuries were partially studied. Two inhabiting levels were also discoovered, one previous and the other subsequent to the necropolis. In the initial phase, the sand bank was probably not inhabited, but used as a clay extraction source. In a second phase it was adorned in several stages with a brown, rough earth over which the dwellinmgs were subsequently built. The first inhabiting level (from bottom upwards) consists of remnants of no. 2 and no. 6 dwellings. After their abandonment, above these complexes lay dwellings 4 and 5, both destroyed by fire. After their burning, probably by the and of the XVth Century or beginning of the XVIth Century this area was used as a necropolis. The inhabitance previous to the necropolis level can be relatively well dated by a Milletus type pottery fragment (this type pottery had been manufactured only before 1470). The necropolis functioned, according to the existing data, till the XVIIth Century. One of the dating elements of the necropolis is a coin discovered in a grave level. This coin was issued during Bayezid II (1481-1512). The inhabiting level subsequent to the end of the necropolis can be dated mainly using several pottery fragments manufactured at Iznik in the second phase (post 1525), a pipe fragment and an ear ring (discovered in the area of dwelling no. 1) dating back from the XVIIth Century.
\end{abstract}

\section{Burial rite and ritual}

Burial was the rite from the sand bank no. 3 necropolis burial, at least as shown by existing data.

The burial ritual was Christian, with a East - West general orientation, with eventual South-East or North-West deviations due to the season when the burial took place.

Out of the 25 studied graves, 12 of them contained a coffin (M. 41, 42, 43, 44, 45, 46, 47, 48, 49, $50-?, 52,53,60)$. In the case of M50 we cannot be sure whtether the body was deposed in a coffin or not. Out of these, two belonged to children (M.41 and M.45) and nine to adults. In the case of M. 47, it is hard to precise whether it belonged to a child or an adult. A child was discovered also in M. 50.

In one case, M. 54, we observed that the reburial was practised. Double burials or of a pregnant woman was observed at M. 43. Here, bone fragments belonging to a child were discovered in the pelvian area.

In what regards the positions of the deceased, we observed that most of them were laid on their backs. The exceptions are only the disturbed graves and M. 55, laid on the belly.

The deceased arms ' positions are: a hand by the body and the other with the hand on the pelvis (AB)-M.42, with both arms along the body, and hands on the pelvis (B)-M. 43, 44, with a hand on the pelvis and the other on the abdomen (BC)-M.60, with arms flexed from the elbow and hands on the abdomen (C)-M. 50, 52, 53, an arm on the abdomen and the other on the thorax (CD)-M. 56, an arm on the abdomen and the other flexed from the elbow, with the hand lain on the clavicula (CE)-M. 49, arms flexed from the elbow and hands on the thorax (D)-M. 41, arms flexed from the elbow and hands on the clavicles (E)-M. 46.

In the case of M. 48 we established the position of only one arm, with the hand on the clavicle (EX). 
The high variety of arm positions of the deceased is a characteristic of the medieval period, especially in the territories from the Northern part of the Lower Danube.

The legs of the deceased were generally stretched and parallel. There are nevertheless several exceptions. M.41, where the femurs formed towards the knees an orthogonal angle, makes me think that the body was deposed having its legs crossed. In the case of M.43, legs were deposed being very closely grouped in the knees' area, while the lower parts were again distanced towards the feet. M. 60 had the right leg flexed from the knee towards the exterior and the left stretched. M. 8/2002 was possibly deposed with the legs slightly flexed from the knee towards the left, but this was the position only of the left leg, as the right was completely disturbed.

Fragments of burnt wood were discovered in several graves. Unfortunately, due to the fact that several graves cut an inhabiting level containing also burnt wood, we cannot be certain if the discovery is the sign of intended practices or was simply included in the grave during the digging. The second hypothesis is the most probable.

\section{Funeral inventory}

Out of the 25 graves researched during the last three campaigns, 11 contained a funeral inventory. This inventory is nevertheless relatively poor and consists of costume pieces (a buckle and several buttons made of silver leaflet) and hands adornments (three rings).

\section{Costume pieces}

1. The buckle was manufactured in iron. It is a typical piece for necropoles along the Danube basin. Such pieces were also discovered at Branicevo and Cladova (Arad County). They had a wide circulation in time and can be dated also from the the XVth Century.

2. Globular buttons made of silver leaflets are frequent pieces for such necropoles. Some pieces have a hole in their upper part. They were attached by a small handle made of silver wire The pieces are worked in two hemispheres welded one to the other. Here these were dated back to the XVIIth Century.

\section{Adornment pieces}

1. Ring made of a twisted silver wire to whom a rhomboidal-shaped chaton was welded. Such pieces were dated at the Oraşul de Floci as being from the XVIth Century as well as the first half of the XVIIth Century. At Enisala, pieces with similar manufacturing features were dated from the last two decades of the XVth Century and from the first two decades of the XVIth Century.

2. Ring made of wire (probably silver) with a welded chaton in the shape of a pill. The link has a circular section.

3. Silver ring manufactured by moulding. The chaton has a casket placed to fix a stone socket (have discovered). The chaton has a circular shape and has its outer part decorated with vegetal motifs. The link is triangular and was decorated.

Because of the existing stratigraphic situation and of the pieces recovered from the first inhabiting level (Miletus type pottery, whose manufacture stopped in 1470), as well as from the graves (rings, buttons) or near them (coin issued in the time of Bayezid II), I presume that the necropolis can be dated since the end of the XVth Century - beginning of the XVIth Century till the XVIIth Century. V. Rădulescu and A. Păunescu mention the drilling by the graves of an inhabiting level dating from the beginning of the XVIth Century, using a coin issued in the time of Ferdinand Ist, in the year 1530. The fact that no graves have been discovered in the 1/2003 area may prove that this was the graveyard's Northern limit. The inhabitance was resumed after the abandonment of the necropolis, sometime during the second half of the XVIIth Century (towards its end). The pieces that confirm this fact are the ring discovered in the area of dwelling 1/2002 and the pipe. Both pieces can be dated back to ther before mentioned period. More evidence is given by several Iznik Second Phase pottery fragments, that can be dated as post 1525. These fragments were discovered in the upper part of a domestic waste dump hole, from the level above the one with the burials. These fragments belong to cups and plates and are decorated with green and blue vegetal motifs. 
În anul 2001, cercetarea sitului arheologic Oraşul de Floci (pl. I) a fost reluată şi în partea stângă a şoselei Bucureşti-Constanța ca urmare a faptului că această porțiune nu aparține zonei protejate. La aceasta se adaugă faptul că în acest moment pe grindul nr. 3 nu mai există nici o construcție contemporană funcțională, iar cele care au existat au fost dezafectate. De asemenea, zona urmează, foarte probabil, să devină loc de amplasare a unor alte amenajări. În aceste condiții, s-a încercat efectuarea unei cercetări de salvare care să completeze datele arheologice cunoscute până în prezent. Scopul principal a fost acela de a obține noi date asupra necropolei sondată în anii $1976,1979^{1}$ şi $1982^{2}$ şi a etapelor de locuire ante şi post funcționare a cimitirului. Până în prezent s-au desfăşurat trei campanii de săpături după cum urmează: prima desfăşurată în anul 2001 cu un colectiv format din Elena Renţa şi Radu Coman (Muzeul Județean Ialomița), a doua, în 2002 (Silviu Oța - M.N.I.R. şi Radu Coman), iar ultima în anul 2003 (Gheorghe Matei - M.J.I. şi Silviu Oța). Fondurile au fost asigurate în totalitate de către Muzeul Județean Ialomița. Locația materialului descoperit este la Muzeul Județean Ialomița, iar o parte a documentației la M.N.I.R.

În campania arheologică din vara anului 2002, s-a continuat cercetarea mormintelor din caseta 1/2001 (orientată puțin deviat pe direcția SV-NE). Aceasta a avut dimensiunile de 2,50 m x $10,00 \mathrm{~m}$ şi a fost amplasată la nord de şoseaua BucureştiConstanța, în dreptul magazinului din parcarea de la km. 105. La vest de aceasta a fost deschisă o nouă casetă având aceleaşi dimensiuni. Caroiajul a fost făcut de la est la vest, din 2,5 m în 2,5 m. Martorul lăsat între cele două casete a avut lățimea de $1,00 \mathrm{~m}$. Săpăturile au avut un caracter de salvare şi au urmărit cercetarea necropolei nr. 3 de pe grindul trei şi a locuirii anterioare şi posterioare ei. La nord de caseta 1/2002, a

\footnotetext{
*Text redactat de Silviu Oța.

${ }^{1}$ Chițescu et alii 1981, 131, Fig. 7/1, 3, 4, 137, 139.

2 Păunescu 1984, 143-148.
}

fost trasată o alta (C. 1/2003) cu aceleaşi dimensiuni. Martorul dintre cele două avea lăţimea de 1,00 m. La est de această casetă, a fost trasată secțiunea 1/2003, cu dimensiunile de $2,5 \mathrm{~m} \times 24 \mathrm{~m}$, având aceeaşi orientare. Martorul dintre ele este de 0,50 m. Paralel cu S. 1/2003 şi la sud de ea a fost trasată şi S. 2/3003. Aceasta este în prelungirea C.1/2001, până la capătul S.1/2003. Din aceste ultime două secțiuni vom analiza doar mormintele cercetate până la data de 9.08. 2003.

\section{Caseta 1/2002}

Sub stratul de pământ arabil a fost surprinsă locuința $n r .1$ în carourile 1-2 la adâncimea de $-0,33-0,35 \mathrm{~m}$. Aceasta constă într-o podea de lut cu grosimea de $0,10 \mathrm{~m}$ observabilă în plan şi pe profilele de nord şi de est ale secțiunii. Pereții construiți din chirpic, au fost incendiați. Sub acest complex a fost un strat de pământ de culoare bej, bătătorit, surprins în carourile 1-2. La adâncimea de $0,50 \mathrm{~m}$. a fost surprinsă $\mathrm{o}$ podea de lut cu grosimea de 0,12-0,20 m (locuința 2/2002). În colțul de $\mathrm{NE}$ al secțiunii, corespunzător acestui complex a fost descoperit un fragment de cuptor (lățimea sa pe profilul estic este de $1,00 \mathrm{~m}$ ). Ultima podea de lut menținată a fost amenajată pe un strat de pământ marozgrunțuros cu grosimea de $0,10-0,15 \mathrm{~m}$.

Între locuințele $1 / 2002$ şi $2 / 2002$, sub pereții de chirpic incendiați, a fost descoperit un cercel din argint cu pandantiv pe care a fost fixată o pastilă din pastă de sticlă de

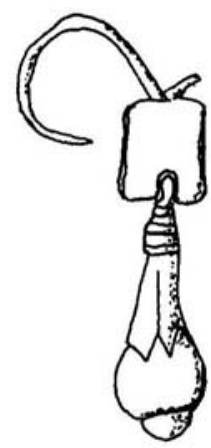
culoare verde. Acest tip de piesă se poate data pe baza analogiilor din acelaşi sit în sec. XVII ${ }^{3}$. Lângă locuința $2 / 2002$ au fost găsite trei gropi de diverse dimensiuni, pline cu cenuşe. (G.2/2002$1,10 \mathrm{~m} \times 0,90 \mathrm{~m}$, G.3/2002$0,60 \mathrm{~m} \times 0,40 \mathrm{~m}, G .4 / 2002$ $\mathrm{m}-0,60 \times 0,40 \mathrm{~m})$. Acestea mai conțineau fragmente ceramice, resturi

\footnotetext{
${ }^{3}$ Anton-Manea 2000, 114, 128, fig. 49.
} 
osteologice, o cute şi o plăcuță de bronz. În acest strat a fost descoperit un fragment ceramic de Milet (sec. XV). Între Locuințta $1 / 2002$ şi Locuința 2/2002 au fost descoperite morminte $(M .5,6 / 2002)$. Între cele două locuințe a fost descoperită o groapă pentru depozitarea rezidurilor menajere. (G.1/2002 cu diametrul de $0,90 \mathrm{~m}$ şi o adâncime de $0,90 \mathrm{~m})$. Aceasta este anterioară locuinței $1 / 2002$ şi posterioară locuinței 2/2002.

Locuința 3/2002, cercetată parțial, a fost surprinsă în carourile 2-4 la adâncimea de $0,40 \mathrm{~m}$. Din ea s-a mai păstrat o podea de lut cu grosimea de $10 \mathrm{~cm}$. Surprinsă în plan şi pe profilul nordic.

Locuința 4/2002, cercetată parțial, a fost identificată în carourile 3-4 ale C. $1 / 2002$. A fost găsită la adâncimea de 0,40 $\mathrm{m}-0,50 \mathrm{~m}$. Este observabilă atât în suprafaţa secțiunii cât şi pe profilurile de sud şi de vest ale casetei. Aceasta constă dintr-o podea de lut cu grosimi variabile, de la 0,05 $\mathrm{m}$ până la $0,10 \mathrm{~m}$. Podeaua a fost amenajată pe un nivel de pământ maro-zgrunţuros cu grosimea de $0,30 \mathrm{~m}-0,55 \mathrm{~m}$. Locuința suprapune o groapă menajeră cu mai multe faze de umplere, cu diametrul de $1,30 \mathrm{~m}$ şi adâncimea de $0,70 \mathrm{~m}$, măsurat de sub nivelul de construcție. Groapa a tăiat nivelul de pământ maro-zgrunțuros. Acest pământ suprapunea sterilul arheologic în care au fost făcute mici gropi pentru scoaterea lutului. Amenajarea grindului cu pământ marozgrunţuros a fost realizată în mai multe etape. În acest sens stau dovadă mici lentile de lut şi vetre izolate care nu au aparținut unor locuințe.

Locuința 5/2002, cercetată parțial, este observabilă pe profilul nordic al casetei $1 / 2002$, în carourile $1-3$, sub locuințta 3/2002. Aceasta consta într-o amenajare de lut cu grosimi variabile $(0,05 \mathrm{~m}-0,10 \mathrm{~m})$ pe stratul de amenajare, maro zgrunțuros. Peste ea, în carourile 1 şi 2 a fost o podea de lemn cu grosimea de $0,06 \mathrm{~m}$. În elevație, clădirea a avut pereții din chirpic şi a fost distrusă prin incendiere.

Locuința 6/2002, cercetată parțial. Se observă pe profilul sudic şi pe cel vestic al secțiunii din care s-a mai păstrat o podea de lut bătătorit cu grosimea de 4-6 cm şi care a fost amenajată pe pământul marozgrunțuros. Era orientată NV-SE, asemenea tuturor celorlalte locuințe.

Conform analizei stratigrafice, de jos în sus, se poate spune că în această parte a grindului, inițial s-au practicat gropi pentru scoaterea lutului. Peste ele, la un moment dat, probabil în cursul secolului XV a avut loc o amenajare a zonei cu pământ marozgrunţuros în mai multe etape. Peste acest nivel de amenajare au fost ridicate locuințe. În campania 2002 a fost surprinsă locuința $2 / 2002$ şi 6/2002. Cauzele abandonării lor în acest stadiu al cercetării ne scapă. Ambele par a fi fost contemporane. Peste locuința 6/2002 a fost găsit un strat de pământ maro, fin amestecat cu urme de lemn ars. Acelaşi tip de pământ a fost găsit şi peste locuința $2 / 2002$.

Peste locuința 6/2002 a fost amenajată locuința 4/2002. Contemporană cu ea, pare să fi fost locuința 5/2002. Ambele au fost incendiate. Peste cele două complexe menționate, a fost amenajată o necropolă. După abandonarea cimitirului s-a reluat pe locul său ridicarea de locuințe. Aceasta este atestată prin complexele 1şi 3/2002. Primul a încetat să mai fie utilizat în urma unui incendiu. Urme ale unei arderi puternice se mai observă şi în caroul 4 al casetei. Locuința 3/2002 pare să fie posterioară Locuința 1/2002. Datarea locuinței 1/2002 se poate realiza prin prezența unei pipe ce se poate încadra cronologic în sec. XVIIXVIII.

În anul 2003 a fost trasată o nouă casetă (C 1/2003, 2,5 m x $10 \mathrm{~m}$ ) paralelă cu C 1/2002. Martorul dintre ele are o lățime de $1 \mathrm{~m}$. În această casetă nu au fost descoperite morminte, ceea ce ne face să credem că în acolo trebuie să fie limita nordică a necropolei. În continuarea C $1 / 2003$, spre est, cu un martor de $0,50 \mathrm{~m}$ a fost trasată $\mathrm{S}$ 1/2003 (2,5 m x $24 \mathrm{~m})$. Acolo au fost găsite resturi osteologice umane, bulversate însă, în carourile $5-6$, la adâncimea de $-0,30 \mathrm{~m}$. În caroul 7, a fost descoperit, passim, un inel de argint cu montură, dar aceasta din urmă 
lipseşte. $\mathrm{Nu}$ este exclus ca piesa menționată să provină de la mormântul deranjat. Tot în S $1 / 2003$, în caroul 1 , la $-0,38 \mathrm{~m}$, în zona locuinței $1 / 2002$ a fost descoperit un cercel de argint cu pandantiv pe care a fost montată o pastilă de pastă de sticlă de culoare verde. Contextul în care a fost găsită, între resturi de pereți ai locuinței distrusă prin incendiere şi o reamenajare parţială pe molozul rezultat din prima dezafectare a complexului, dar şi datorită faptului că sub aceste locuințe se află o necropolă nu exclude posibilitatea ca piesa să provină de la un mormânt deranjat, fiind antrenată într-un fel sau altul şi ajungând în acea poziție. Paralel cu această secțiune, la sud de ea şi în continuarea $\mathrm{C}$. $1 / 2002$ a fost trasată $S$ 2/2003, din dreptul caroului 5 până în caroul 12 .

Până la campania din anul 2001 au mai fost cercetate două morminte în anul 1976, 11 în 1979 şi 28 în anul $1982^{4}$. Numerotarea din anul 2001 o vom începe de la ultimul cercetat în anul 1982, adică de la M.41.

\section{Descrierea mormintelor din caseta $1 / 2001$ (pl. II)}

M. 41 (1/2001) - mormânt plan, individual, a aparţinut unui copil. A fost înmormântat în sicriu de lemn din care s-au recuperat cuie şi piroane de fier. Orientat SV-NE, fundul gropii a fost surprins la $1,07 \mathrm{~m}$ de la nivelul actual de călcare ${ }^{5}$. Defunctul era depus pe spate, cu palmele pe torace. Picioarele au fost aşezate în $X$. Inventarul funerar constă dintr-un nasture metalic de formă globulară.

M. 42 (2/2001) - mormânt plan, individual, a aparţinut unui adult. A fost înmormântat în sicriu de lemn. Orientat SV$\mathrm{NE}$, iar fundul gropii a fost surprins la o adâncime de 1,03 m. Defunctul era depus întins pe spate cu mâna stângă pe lângă corp

\footnotetext{
${ }^{4}$ În articolul publicat în anul 1984 în CA VII, la p. 144, A. Păunescu menționează cercetarea a 18 morminte până în 1982, nu 13 câte au fost amintite de V. Rădulescu în anul 1981. La p. 143 a fost amintită de către A. Păunescu cifra de 16 morminte pentru aceeaşi necropolă!

${ }^{5}$ Toate adâncimile la care sunt prezentate morminte sunt măsurate de la nivelul actual de călcare.
}

iar dreapta cu palma pe bazin. Picioarele sunt întinse şi paralele. Inventarul funerar constă dintr-un inel de argint cu veriga torsionată, cu chaton rombic sudat pe ea, şi o mică sferă metalică, probabil un bumb.

M. 43 (3/2001) - mormânt plan, individual, a aparținut unui adult. A fost înmormântat în sicriu de lemn. Orientat SV$\mathrm{NE}$, iar fundul gropii a fost surprins la o dâncime de 0,80. Defunctul era depus în groapă întins pe spate, cu palmele aşezate pe bazin. Piciorul stâng a fost descoperit întins, iar dreptul deranjat, cu capătul femurului apropiat de genunchiul stâng. Inventarul funerar constă dintr-un bumb metalic sferic, cu tortiță. În groapă, în zona abdomenului sau găsit oase de la un copil.

M. 44 (4/2001) - mormânt plan, individual, a aparținut unui adult. A fost înmormântat în sicriu de lemn din care s-au recuperat cuie de fier. Groapa avea contur dreptunghiular. Scheletul era orientat SV$\mathrm{NE}$, iar fundul gropii a fost atins la o adâncime de 1,03 m. Defunctul a fost depus în groapă întins pe spate, cu palmele aduse pe bazin. Picioarele sunt întinse şi paralele. Inventarul funerar constă dintr-un bumb sferic din metal, cu tortiță.

M. 45 (5/2001) - mormânt plan, individual, a aparținut unui copil. A fost înmormântat în sicriu de lemn din care s-au recuperat cuie din fier. Orientarea nu se poate stabili datorită faptului că mormântul a fost puternic deranjat. Mormântul a suprapus pe M.6/2001. Adâncimea la care a fost găsit este de $0,82 \mathrm{~m}$. Nu a avut inventar funerar.

M. 46 (6/2001) - mormânt plan, individual, a aparţinut unui adult. A fost înmormântat în sicriu de lemn. Orientat SV$\mathrm{NE}$, iar fundul gropii a fost surprins la o adâncime de 0,94 m. Defunctul a fost depus pe spate, cu mâinile flectate din cot şi palmele aduse pe clavicule. Picioarele sunt întinse şi paralele. $\mathrm{Nu}$ a avut inventar funerar.

M. 47 (7/2001) - mormânt plan, individual, a aparținut unui adult. A fost înmormântat în sicriu de lemn. Forma gropii este dreptunghiulară. Orientat SV-NE, iar fundul gropii a fost surprins la o adâncime de 11-14 m. Mormântul este suprapus parțial 
de M. 8 şi M.9 şi este deranjat. Nu a avut inventar funerar.

M. 48 (8/2001) - mormânt plan, individual, a aparținut unui adult. A fost înmormântat în sicriu de lemn de la care s-au recuperat cuie de fier. Orientat SV-NE, iar fundul gropii a fost surprins la o adâncime de $0,95 \mathrm{~m}$. Defunctul a fost depus pe spate cu mâna stângă flectată din cot, cu palma adusă pe claviculă. Picioarele sunt întinse şi paralele. $\mathrm{Nu}$ a avut inventar funerar.

M. 49 (9/2001) - mormânt plan, individual, a aparținut unui adult. A fost înmormântat în sicriu de lemn de la care sau recuperat cuie, scoabe şi piroane de fier. Orientat SV-NE, fundul gropii a fost surprins la o adâncime de 1,05 m. Defunctul era depus pe spate cu mâna dreaptă flectată din cot, cu palma adusă pe claviculă, iar dreapta pe abdomen. Picioarele sunt întinse şi paralele. Inventarul funerar constă în doi nasturi globulari din metal.

\section{Descrierea mormintelor din caseta 1/2002 (pl. III)}

M. 50 (1/2002) - mormânt plan, individual, a aparținut unui copil. $\mathrm{Nu}$ se poate spune cu precizie dacă a fost înmormântat în sicriu de lemn sau nu, deşi între craniu şi umărul stâng a fost descoperit un cui de fier. Orientat SV-NV, a fost surprins la o adâncime de 0,56 -0,60 m. Defunctul a fost depus în groapă întins pe spate, cu palmele depuse pe abdomen. Picioarele sunt întinse şi paralele, dar lipsesc de la genunchi în jos. $\mathrm{Nu}$ a avut inventar funerar. Groapa mormântului a deranjat o zonă de arsură puternică.

M. 51 (2/2002) (?)-din schelet se mai păstrează doar coloana vertebrală, la o adâncime de 0,63-0,65 m.

M. 52 (3/2002) - mormânt plan, individual, a aparținut unui adult. A fost înmormântat în sicriu de lemn. Orientat V-E, a fost surprins la o adâncime de $0,61 \mathrm{~m}$. Forma gropii a fost dreptunghiulară. Defunctul a fost depus pe spate cu palmele pe abdomen. În zona picioarelor, mai jos de genunchi a fost deranjat de o groapă posterioară înmormântării. Inventarul funerar constă în o cataramă de fier găsită în partea superioară a bazinului, un fragment de monedă (?) la dreapta craniului, în zona gurii şi câțiva bumbi metalici.

M. 53 (4/2002) - mormânt plan, individual, a aparţinut unui adult. A fost înmormântat în sicriu de lemn. Orientat V-E, a fost surprins la o adâncime de $0,58 \mathrm{~m}$. Defunctul a fost depus pe spate, cu palmele pe abdomen. Picioarele sunt întinse şi paralele. Inventarul funerar constă într-un inel descoperit la mâna dreaptă.

M. 54 (5/2002) - din acest mormânt (copil) s-au mai recuperat doar craniul şi câteva oase. Inventarul funerar constă din un bumb de metal. A fost găsit la o adâncime de $0,50 \mathrm{~m}$. Pare a fi vorba de o reinhumare.

M. 55 (6/2002) - mormânt plan, individual, a aparținut unui adult. Orientat V$\mathrm{E}$, a fost descoperit la adâncimea de $-0,60 \mathrm{~m}$. Cercetat parțial. Defunctul a fost aşezat în groapă în poziția decubit ventral. Inventarul funerar constă într-un bumb din metal.

M.56 (7/2002) - mormânt plan, individual, a aparţinut unui copil. Orientat SV-NE, a fost descoperit la adâncimea de $0,83 \mathrm{~m}$. Defunctul era depus întins pe spate, cu mâna stângă pe abdomen. Mâna dreaptă are oasele radius şi cubitus pe torace şi lângă torace. Fragmente din palmă s-au găsit pe abdomen. Picioarele sunt întinse şi paralele. Inventarul constă din trei nasturi globulari din metal.

M.57 (8/2002) - mormânt plan, individual, puternic deranjat a aparținut unui copil. Orientat SV-NE, a fost descoperit la adâncimea de $0,82 \mathrm{~m}$. În groapă s-au găsit fragmente de cărbune. $\mathrm{Nu}$ a avut inventar funerar.

M.58 (9/2002) - mormânt plan, individual, a aparţinut unui copil. Orientat V-E. Forma gropii este dreptunghiulară. Scheletul este în stare proastă de conservare.

Între morminte, în caroul 3, la $-0,50$ m. a fost descoperită o monedă otomană (mangâr) emisă în timpul sultanului Bayezid II (1481-1512) ${ }^{6}$.

\footnotetext{
${ }^{6}$ Mulțumim pe această cale domnului Aurel Vâlcu pentru determinarea piesei.
} 
Descrierea mormintelor din secțiunea $1 / 2003$

M. 59 (1/2003) - mormânt plan, deranjat în totalitate. A fost descoperit în caroul 6 , la $-0,30 \mathrm{~m}$. Din schelet s-au recuperat doar un fragment de femur şi câteva coaste. În caroul 7 s-a descoperit un inel de argint, la aproximativ $-0,33 \mathrm{~m}$. Din caroul $5, \mathrm{la}-0,30 \mathrm{~m}$, din acelaşi context stratigrafic, provine un pinten cu rozetă, fragmentar.

\section{Descrierea mormintelor din secțiunea 2/2002}

M. $60(2 / 2003)$ - mormânt plan, descoperit în caroul 5 , la $-0,85 \mathrm{~m}$. Scheletul a aparținut unui adult. A fost depus în sicriu, în poziția decubit dorsal. Capul era înclinat spre dreapta cu $45^{\circ}$. Mâna stângă a fost depusă pe abdomen, iar dreapta cu palma adusă pe bazin. Mormântul a suferit unele deranjamente, în groapă, de-a lungul picioarelor fiind găsite oase de la palmă. Piciorul drept a fost flectat din genunchi spre exterior, iar stângul era întins. În pământul de umplutură am găsit urme de lemn carbonizat, sub capacul sicriului.

M.61 (3/2003) - mormânt plan, descoperit în caroul 5, a aparținut unui copil. Adâncimea: - $0,70 \mathrm{~m}$. A fost complet distrus. $\mathrm{Nu}$ s-a recuperat decât maxilarul inferior, pe care au fost găsiți dinți de lapte şi câteva coaste.

M.62 (4/2003)-mormânt plan, descoperit în carourile 5-6, a aparținut unui adult. Distrus recent.

M.63 (5/2003) - mormânt plan, descoperit în caroul 5, a aparținut unui copil. Distrus aproape în totalitate. In situ a mai fost descoperit doar un picior şi jumătate de bazin. Lungimea totală a oaselor păstrate este de 28 $\mathrm{cm}$. Orientarea $255^{\circ} \mathrm{N}$, cu capul spre vest. Adâncimea: $-0,85 \mathrm{~m}$. Nu pare să fi avut inventar funerar. În plan a fost descoperit la stânga piciorului M. 60, la o distanță de $35 \mathrm{~cm}$. Un fragment de craniu de copil a fost descoperit între laba piciorului M. 60 şi piciorul M. 62, la $8 \mathrm{~cm}$ de acesta din urmă. Probabil că mormântul acesta a fost deranjat la un timp relativ scurt după înmormântare. $\mathrm{Nu}$ s-a recuperat inventar funerar.
M.64 (6/2003) - mormânt plan cercetat parțial, descoperit în profilul de vest al secțiunii. S-au descoperit doar oase de la mâini. Stânga a fost depusă pe abdomen. Adâncimea: $-0,75 \mathrm{~m}$.

M.65 (7/2003) - mormânt de adult, deranjat în partea superioară a scheletului. Picioarele erau întinse şi paralele. Orientare: $264^{\circ} \mathrm{N}$. Adâncimea: $0,85 \mathrm{~m}$. O bucată de bazin a fost găsită între M. 64 şi M. 60 .

\section{Ritul şi ritualul de înmormântare}

Din punct de vedere al ritului, în necropola de pe grindul $3 \mathrm{~s}$-a constatat până în prezent practicarea inhumației.

Ritualul de înmormântare este cel creştin, cu orientarea mormintelor pe direcție vest-est, eventual cu abateri spre sud-est sau nord-vest în funcție de anotimpul de înmormântare.

Din 25 morminte cercetate, s-a constatat că 12 au avut sicriu (M. 41, 42, 43, $44,45,46,47,48,49,50-?, 52,53,60)$. În cazul lui M. $50 \mathrm{nu}$ se poate spune cu certitudine dacă a fost depus în sicriu sau nu. Dintre acestea, două au aparținut unor copii (M. 41 şi M. 45), iar nouă unor persoane adulte. Despre M. 47 este greu de precizat dacă a aparținut unui individ adult sau unui copil. Tot un copil a fost descoperit în M. 50.

Într-un caz, M. 54, s-a constatat practicarea reinhumației.

Înmormântări duble sau a unei femei însărcinate s-a constatat în cazul lui M. 43, la care în zona abdomenului s-au găsit resturi din oasele unui copil.

În ceea ce priveşte poziția defuncților se constată că în marea majoritate au fost depuşi întinşi pe spate. Excepție fac doar mormintele deranjate şi M. 55 care a fost depus culcat pe burtă.

Poziția brațelor defuncților este după cum urmează:

Cu o mână pe lângă corp şi cealaltă cu palma pe bazin $(\mathrm{AB})^{7}$-M.42.

$\mathrm{Cu}$ brațele depuse pe lângă corp, iar palmele depuse pe bazin (B)-M. 43, 44.

\footnotetext{
${ }^{7}$ Oța 2000, 165-166, Oța 1998, 116.
} 
Cu o palmă depusă pe bazin, iar mâna cealaltă pe abdomen (BC)-M.60.

$\mathrm{Cu}$ brațele flectate din cot şi cu palmele pe abdomen (C)-M. 50, 52, 53.

Un braț pe abdomen, iar celălalt pe torace (CD)-M. 56.

Un braț pe abdomen şi celălalt flectat din cot cu palma adusă pe claviculă (CE)-M. 49.

$\mathrm{Cu}$ brațele flectate din cot şi palmele depuse pe torace (D)-M. 41.

$\mathrm{Cu}$ brațele flectate din cot ci palmele aduse pe clavicule (E)-M. 46.

În cazului lui M. $48 \mathrm{nu}$ s-a putut stabili decât poziția unui braț, anume cu palma adusă pe claviculă (EX).

Marea varietate a poziției brațelor la defuncți este o caracteristică a evului mediu, mai ales în teritoriile de la nordul Dunării de jos.

Picioarele celor inhumați de regulă erau întinse şi paralele. Excepție fac M. 41 la care femurele formau un unghi de aproximativ $90^{\circ}$ spre genunchi, ceea ce mă face să cred că picioarele au fost depuse încrucişat. În cazul lui M. 43, picioarele au fost depuse foarte apropiate în zona genunchilor, ca părțile inferioare să fie din nou distanțate spre labele picioarelor. M. 60 avea piciorul drept flectat din genunchi spre exterior, iar cel stâng întins. M. 8/2002 este posibil să fi fost depus cu picioarele uşor flectate din genunchi spre stânga, dar în această poziție nu a mai fost găsit decât stângul, dreptul fiind complet deranjat.

În gropile unor morminte s-au descoperit urme de lemn ars. Din păcate, datorită faptului că gropile unor morminte au tăiat un nivel de locuire care conținea şi lemn ars, nu putem spune cu certitudine dacă ceea ce am descoperit în gropi se datorează unor practici intentionate, sau a fost antrenat în timpul săpării mormintelor. Cel mai probabil este vorba de a doua ipoteză.

\section{Inventarul funerar}

Din totalul de 25 de morminte cercetate în ultimele trei campanii, 11 au avut inventar funerar. Acesta este însă relativ sărac şi constă în piese de port (o cataramă şi câțiva nasturi din foiță de argint) şi podoabe de mâini (trei inele).

\section{Piesele de port ${ }^{*}$}

Catarama a fost lucrată din fier. Este o piesă tipică în necropolele din bazinul Dunării. Asemenea piese au mai fost descoperite la Branicevo şi la Cladova (jud. Arad) ${ }^{8}$. Ele au avut o largă circulație în timp, şi pot fi datate şi în cursul sec. XV.

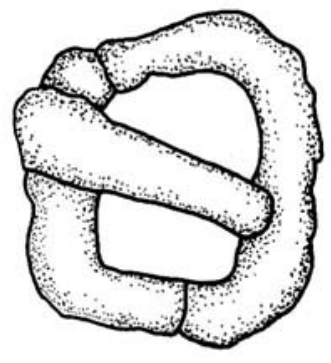

Nasturii globulari din foiţă de argint sunt piese frecvent întâlnite în astfel de necropole. În partea superioară unele piese au o perforație în foiță. Pentru prindere au o urechiuşă din sârmă de argint. Piesele sunt lucrate din două calote semisferice sudate între ele. La Oraşul de Floci au fost datați până în sec. XVII.

\section{Piese de podoabă}

Inel din o sârmă de argint torsionată la care a fost sudat un chaton de formă rombică. Astfel de piese au fost datate la Oraşul de Floci

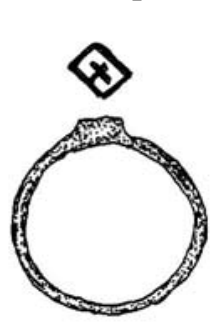
în sec. XVI ${ }^{9}$ dar şi în prima jumătate a secolului XVII ${ }^{10}$. La Enisala piese asemănătoare ca execuție au fost datate în ultimele două decenii ale sec. XV şi primele două din următorul ${ }^{11}$.

\footnotetext{
${ }^{*}$ Toate desenele ale pieselor de port şi podoabelor sunt la scara $1: 1$.

${ }^{8}$ Mulțumim pe această cale domnilor V. Boroneanț şi Gh. Pascu Hurezan pentru materialul inedit pus la dispoziție.

${ }^{9}$ Manea 2000, 111, 123, fig. 18, 19,

${ }^{10}$ Chițescu et alii 1981, 131, Fig. 7/3, 139, Chițescu et alii $1979,220$.

${ }_{11}$ Mănucu-Adameşteanu 1980, 623, fig. 4/3, 624, fig. $5 / 11,625$.
} 
Inel din sârmă (probabil de argint), cu chaton sudat, în formă de pastilă. Veriga este circulară în secțiune.

Inel din argint, executat prin turnare.

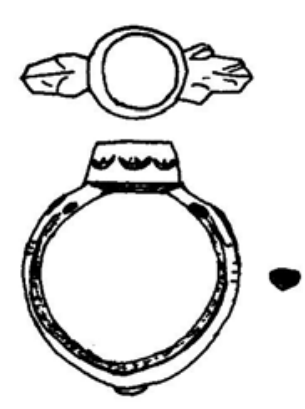

Chatonul are o casetă pentru fixarea monturii (nu a fost descoperită). Chatonul este de formă circulară, decorat pe partea exterioară cu motive vegetale. Veriga este triunghiulară în secțiune şi a fost decorată.

Dată fiind situaţia stratigrafică existentă precum şi piesele recuperate din primul nivel de locuire (ceramică tip Miletus, a cărei producție a încetat în anul $1470^{12}$ ) precum şi cele din morminte (inele, nasturi) sau de lângă ele (monedă emisă în timpul lui Bayezid II), consider că necropola se poate data de la sfârşitul secolului XV începutul sec. XVI până în veacul XVII. V. Rădulescu şi A. Păunescu amintesc de perforarea de către gropile mormintelor a unui nivel de locuire datat la începutul sec. XVI, pe baza unei monede emisă în timpul domniei lui Ferdinand I, în anul $1530^{13}$. De asemenea, faptul că nu s-au descoperit morminte în caseta $1 / 2003$, putem să bănuim că în acea zonă trebuie să fi fost limita nordică a cimitirului. Locuirea a fost reluată după dezafectarea necropolei cândva în cursul sec. XVII, probabil în a doua jumătate, sau spre sfârşitul acestui secol. Piesele care confirmă acest fapt sunt cercelul descoperit în zona locuinţei $1 / 2002$ şi pipa ambele piese putând fi datate în perioada menționată. La aceasta se adaugă câteva fragmente de ceramică de Iznik din faza II, deci databilă după 1525 descoperită în nivelul următor celui în care s-au făcut

\footnotetext{
${ }^{12}$ Mihai 1997, 278.

${ }^{13}$ Chițescu et alii 1981, 137. Este greu de spus în acest moment dacă moneda emisă în 1530 a fost descoperită in situ, sau a ajuns pe podeaua locuinței datorită unor cauze de ordin natural (purtată pe un gang de animal sau împinsă de rădăcina unei plante). Utilizarea ceramicii tip Milletus nu se mai poate justifica în prima jumătate a secolului XVI, la un interval cronologic de minim 30 de ani, după încetarea producției.
}

înmormântările, într-o groapă menajeră, în partea superioară a ei. Aceastea aparțin unor căni şi farfurii şi au ca decor motive vegetale de culoare verde şi albastră.

\section{Bibliografie}

\section{Anton-Manea 2000}

C. Anton-Manea, Podoabe şi accesorii vestimentare descoperite la Oraşul de Floci intre 1975-1989, în Ialomița, III, 2000, 97-139.

\section{Chițescu et alii 1979}

L. Chițescu et alii, Cercetări arheologice la Piua Petri, (Oraşul de Floci), jud. Ialomița, în Cercetări Arheologice, III, 1979.

\section{Chițescu et alii 1981}

L. Chițescu et alii, Cercetări arheologice in anul 1979 la Piua Petri (Oraşul de Floci), comuna Giurgeni, jud. Ialomița, în Cercetări Arheologice, IV, 1981, 120-143.

\section{Mănucu-Adameşteanu 1980}

Gh. Mănucu-Adameşteanu, Necropola medievală de la Enisala Jud. Tulcea, în MCA, a XIV-a sesiune anuală de rapoarte, Tulcea, 1980, 619-625.

\section{Mihai 1997}

D. Mihai, Ceramica de Iznik descoperită la Oraşul de Floci, jud. Ialomița (I), în Cercetări Arheologice, X, 1997, 277-289.

\section{Oța 1998}

I. S. Oța, Mormintele bogomile din sudul Banatului (secolele XII-XV), în Arheologia medievală, II, 1998, 113-123.

\section{Oța 2000}

I. S Oța, Câteva considerații în legătură cu necropolele medievale rurale din sudul Banatului (sec. XII-XV), în Banatica, 15, I, 2000, 161-176.

\section{Păunescu 1984}

A. Păunescu, Cercetările arheologice de la Piua Petri (Oraşul de Floci), com. Giurgeni, jud. Călăraşi, în Cercetări Arheologice, VII, 1984, 143-148. 


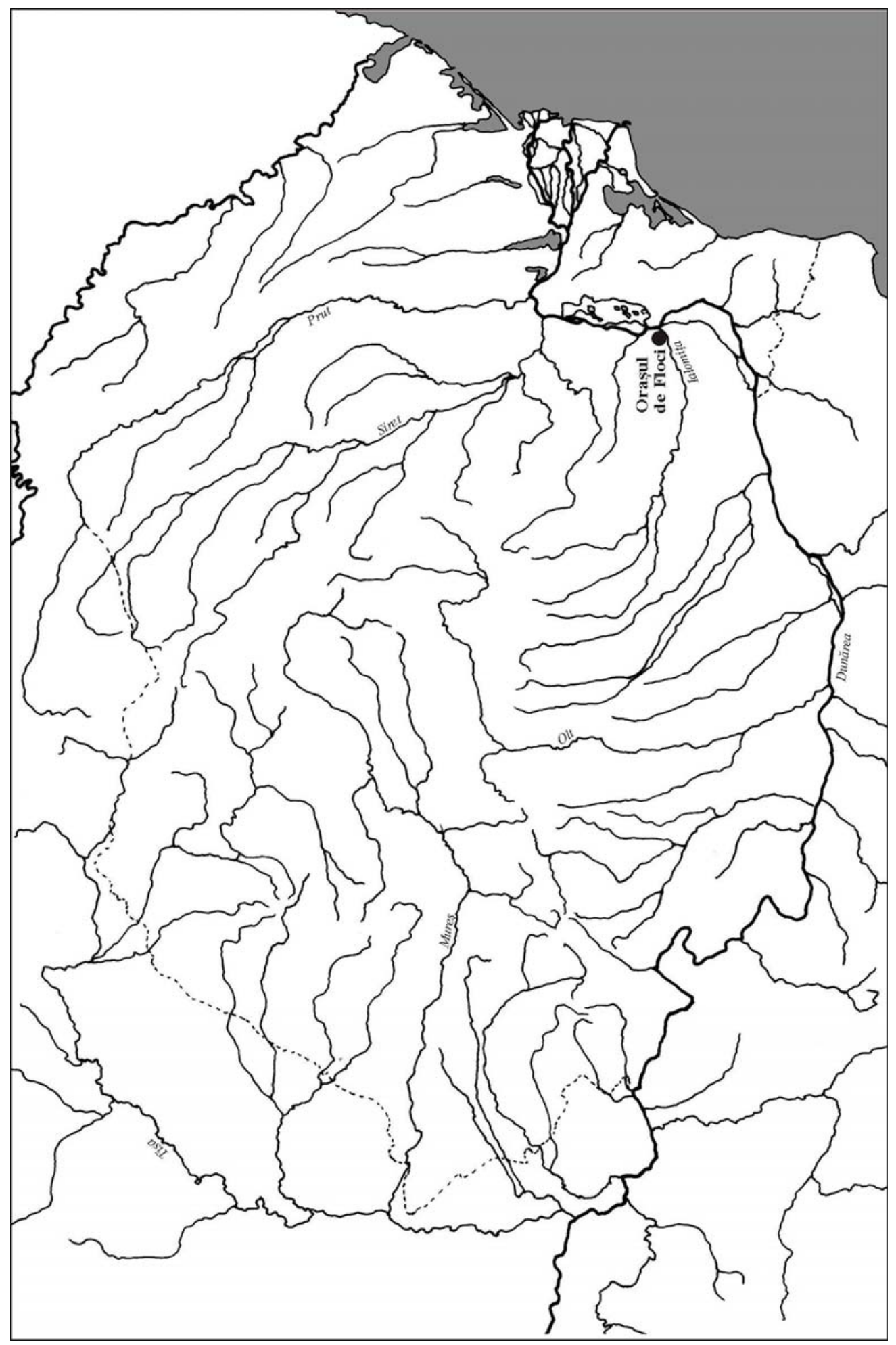

Planşa I. Locaţia sitului arheologic Oraşul de Floci 


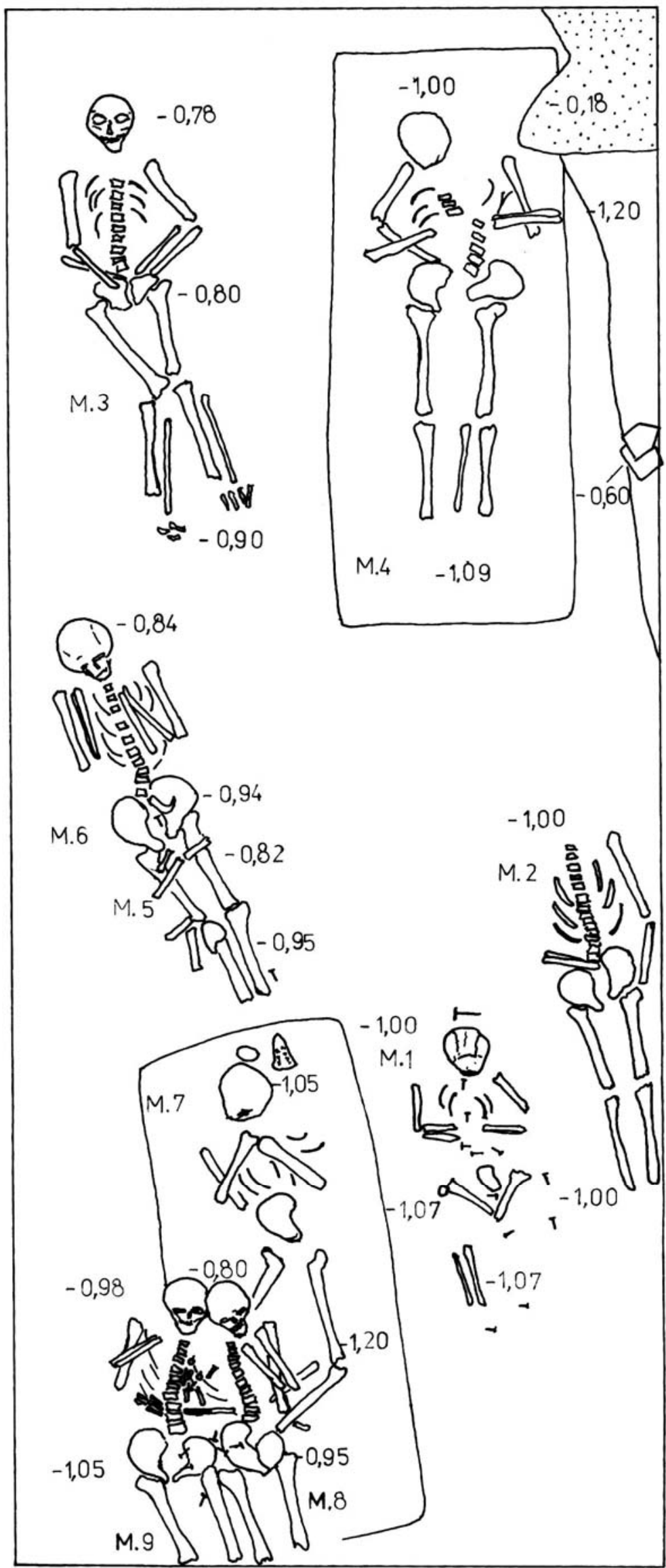

Planşa II

Caseta I/2001

(scara $1: 25$ ) 


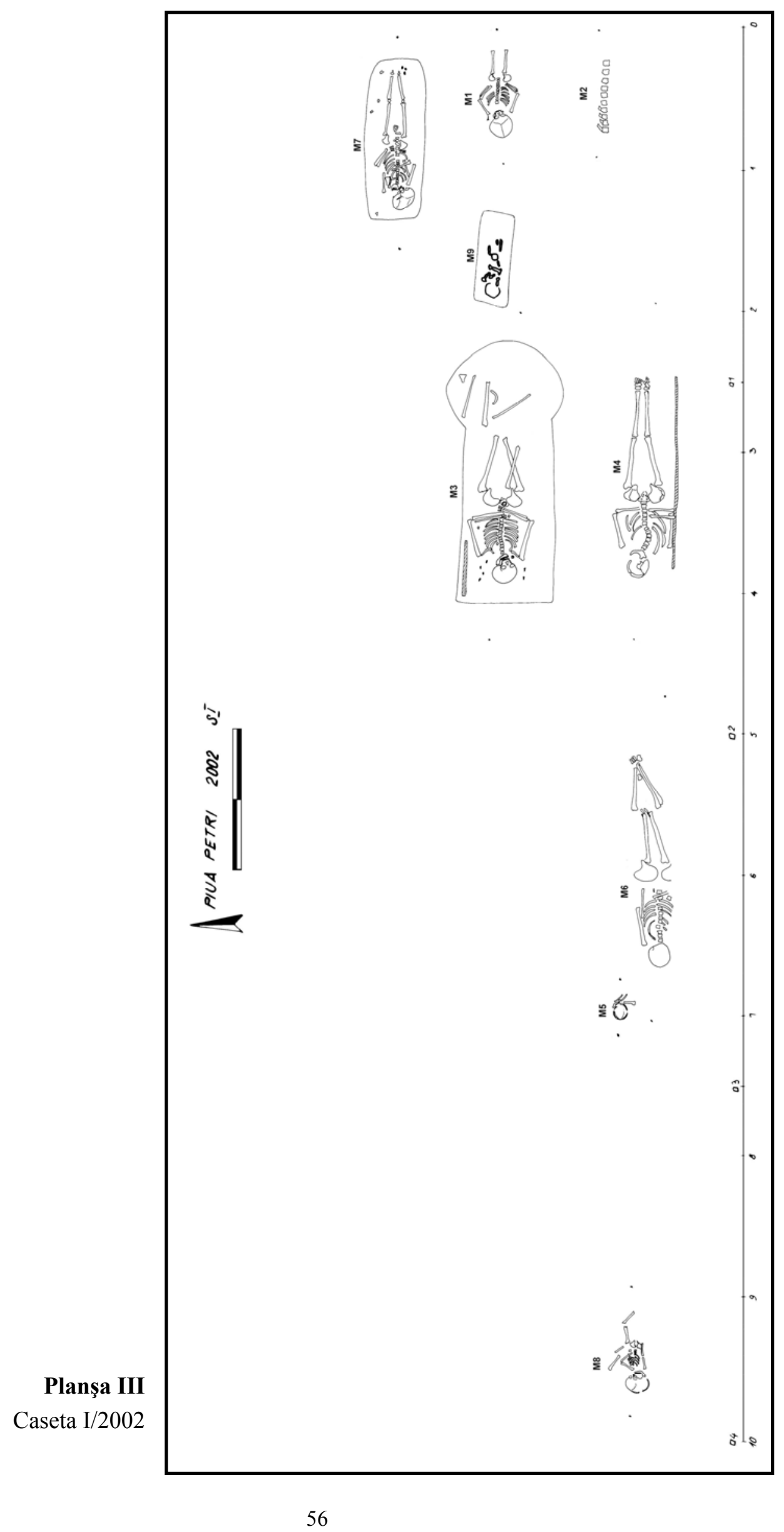

